\title{
PEMBERDAYAAN PEREMPUAN DALAM PELATIHAN PENGURUSAN JENAZAH MELALUI METODE DEMONSTRASI DI KELURAHAN TASIKMADU KOTA MALANG
}

\author{
Laily Fitriani $^{1}$, Muassomah ${ }^{2}$, Ma'rifah Munjiah ${ }^{3}$ \\ 1,2,3 Jurusan Bahasa dan Sastra Arab, UIN Maulana Malik Ibrahim Malang \\ laily@bsa.uin-malang.ac.id,muassomah@bsa.uin-malang.ac.id,munjiah@bsa.uin-malang.ac.id
}

\section{Info Artikel}

\section{Riwayat Artikel:}

Diterima: November 2019

Direvisi: Januari 2020

Diterbitkan: Maret 2020

\section{Keywords:}

Women empowerment Management of Corpse Demonstration Method

\begin{abstract}
Community empowerment as part of activities that are continuously socialized by the government receives very good attention, especially in empowering women. Many efforts have been made by various parties to make this woman empowered, including in the management of bodies where the general public considers that the management of corpse is only a modin task. This study aims to find out how the initial conditions of women in the management of corpse in the Tasikmadu village in Malang and how the process of empowering women and the changes that occur in the management of corpse through demonstration methods in the Tasikmadu village of Malang. This research is a participatory action research (PAR) using the method proposed by Kurt Lewin based on four main components, namely: planning, action, observation and reflection. The results of the study explained that the initial conditions of women in the Tasikmadu village were quite powerful but for empowerment in the management of the remains was minimal, due to the modin as the person in charge of the management of the corpse and the lack of knowledge and skills in the management of the corpse. While the training process uses the demonstration method, which is a method that is carried out by providing direct media, so participants can gain theoretical and practical experience. In the initial cycle, participants explored the theoretical side of corporeal materials in accordance with the Shari'a and corporeal materials. In the second cycle the participants gained firsthand experience to practice the material that had been obtained by the resource persons through puppet media about how to care for the body when experiencing death, bathing, believing, and soliciting to bury the bodies in groups.
\end{abstract}




\section{PENDAHULUAN}

Keberhasilan pembangunan tidak dapat dilakukan secara parsial, melainkan secara bersama-sama. Masyarakat sebagai bagian komunitas memegang kendali untuk menentukan sebuah pembangunan yang berkelanjutan. Perempuan sebagai bagian dalam masyarakat juga memegang peranan penting. Sebagaimana kita ketahui bersama perempuan memiliki andil dalam berbagai program pembangunan yang berawal dari keluarga dan masyarakat.

Pengurusan jenazah sebagai salah satu agenda yang selalu terjadi di masyarakat, biasanya dilakukan oleh seorang modin. Pada kenyataannya, tata cara pengurusan jenazah sendiri telah diajarkan dalam tata cara pengurusan jenazah dalam Islam melalui kitab-kitab fikih yang banyak beredar di masyarakat. utamanya yang diajarkan di hampir semua pondok pesantren. Beberapa buku panduan tentang pengurusan jenazah yang diterbitkan oleh individu atau pondok pesantren beberapa di antaranya sudah beredar di pasar. Tata cara pengurusan jenazah yang meliputi bagaimana mengurus jenazah yang baru meninggal, cara memandikan, cara mengkafani, dan cara mensholatinya.

Pelatihan-pelatihan pengurusan jenazah kepada masyarakat juga sudah diberikan oleh beberapa organisasi Islam seperti Muslimat NU dan Aisyiyah Muhammadiyah. Pelatihan pengurusan Jenazah juga diberikan kepada jajaran modin di beberapa kecamatan, kabupaten dan provinsi (Riyadi, 2013). Pelatihan pengurusan jenazah juga kadang diberikan oleh lembaga atau yayasan seperti pondok pesantren terhadap para santrinya atau warga sekitar pondok pesantren. Akan tetapi, hal yang terjadi di lapangan adalah masyarakat masih beranggapan bahwa mengurus jenazah masih tanggung jawab modin.

Hal ini juga disebabkan oleh keadaan kehidupan masyarakat perkotaan yang cenderung individualistik seringkali menimbulkan berbagai ketimpangan sosial dalam masyarakat. Hal ini bisa menimbulkan kurang memahami kebutuhan antar satu warga dengan yang lainnya, diantaranya adalah dalam hal tata cara pengurusan janazah yang apabila sudah ada tenaga ahli maka yang lain merasa bahwa hal itu bukan tanggung jawab masing-masing. Kesadaran untuk mempelajari, mengetahui, memahami dan mempraktekkan perawatan jenazah belum banyak di tengah-tengah masyarakat. Pandangan dalam masyarakat selama ini banyak yang beranggapan bahwa perawatan jenazah adalah tugas modin, sehingga warga tidak diperlukan mempelajarinya. Sesungguhnya semua warga masyarakat baik laki-laki maupun perempuan memiliki tanggung jawab yang sama dalam perawatan jenazah. Berdasarkan latar belakang diatas, maka peneliti melakukan pengabdian dalam bentuk memberikan motivasi, dan membuka kesadaran warga akan pentingnya pengetahuan perawatan jenazah bagi setiap orang, dengan harapan jika terjadi kematian pada tetangga dan saudara dekatnya bisa langsung dilakukan perawatan jenazah, tidak harus menunggu modin, jika modin berhalang hadir dan memiliki tugas lain pada saat orang tersebut meninggal dunia. Sehingga pelatihan-pelatihan bagi tenaga ahli perempuan untuk mengurus jenazah masih sangat diperlukan. Selain itu saat di lapangan, seringkali terjadi adanya praktek pengurusan jenazah yang masih tidak sesuai dengan ajaran Islam sehingga peneliti merasa perlu untuk menyampaikan pengurusan jenazah yang sesuai dengan ajaran Islam dalam rangka menghargai dan menghormati jenazah.

Kelurahan Tasikmadu merupakan salah satu dari 12 kelurahan yang berada di Kecamatan Lowokwaru dan salah satu dari 57 kelurahan di kota Malang memiliki potensi sumber daya manusia yang masih sangat memungkinkan digali dan dikembangkan untuk kemakmuran masyarakat secara umum. Berdasarkan data statistik kelurahan Tasikmadu, penduduk Kelurahan Tasikmadu 3.354 oarang (49\%) perempuan dan 3.499 orang $(51 \%)$ laki-laki, yang berarti komposisi penduduk yang hampir seimbang ini menjadikan peranan perempuan di kelurahan Tasikmadu dalam perumusan pembangunan mempunyai arti yang sangat penting dan strategis, sehingga harus mendapatkan porsi yang sama besarnya dengan laki-laki dalam bidang pemberdayaan masyarakat. Pemberdayaan masayarakat adalah konsep pembangunan yang berisi nilai-nilai masyarakat untuk membangun paradigm baru dalam pembangunan yang bersifat peoplecentered-participatory, yaitu partisipasi bersumber pada manusia. Dalam hal ini, upaya-upaya pemberdayaan masyarakat harus mampu berperan meningkatkan sumber daya manusia dan memberikan motivasi dan dorongan kepada masyarakat untuk mampu menggali potensi dirinya dan memperbaiki kualitas hidupnya.

Salah satu metode yang dilakukan dalam praktik mengurus dan merawat jenazah adalah metode dokumentasi. Metode ini dapat memberikan gambaran secara utuh karena dalam metode ini peneliti menyajikan materi dengan memperagakan dan mempertunjukkan suatu proses bagaimana merawat jenazah secara langsung melalui media, yaitu boneka (sebagai tiruan manusia). Metode demostrasi efektif digunakan dalam pembelajaran keagamaan, terutama materi fiqh menurut penelitian (Abdullah, 2012), (Nurhayati, 2008). Penggunaan metode dokumentasi ini sesuai dengan penyampaian materi kepada peserta, karena lebih memfokuskan untuk meningkatkan keterampilan mengurus dan merawat jenazah secara langsung dan menjadikan peserta aktif dan kreatif karena terlibat langsung dalam praktek dan pengamatan, serta dapat memberikan kesan mendalam karena pengalamannya dapat langsung diterapkan dalam kehidupan sehari-hari di masyarakat. 
Oleh sebab itu, melalui pelatihan ini diharapkan setiap peserta melalui metode demostrasi mengetahui tata cara mengurus jenazah yang benar sesuai dengan syariat dan diharapkan mampu mengurus jenazah secara individu sehingga setiap keluarga diharapkan mampu mengurus jenazah anggota keluarganya secara benar.

\section{METODE PENELITIAN}

Metode dampingan yang dipakai dalam pengabdian ini adalah Participatory Action Research (PAR). PAR merupakan salah satu model penelitian yang mencari sesuatu untuk menghubungkan proses penelitian ke dalam proses perubahan sosial. Perubahan sosial yang dimaksud adalah bagaimana dalam proses pemberdayaan dapat mewujudkan tiga tolak ukur, yakni adanya komitmen bersama dengan masyarakat, adanya lokal leader dalam masyarakat dan adanya institusi baru dalam masyarakat yang dibangun berdasarkan kebutuhan. Penelitian ini membawa proses penelitian dalam lingkaran kepentingan orang dan menemukan solusi praktis bagi masalah bersama dan isu-isu yang memerlukan aksi dan refleksi bersama, dan memberikan kontribusi bagi teori praktis.

Metode action research ini digunakan untuk tidak membuat masyarakat dampingan sebagai obyek, tetapi menjadikannya sebagai subyek penelitian. Warga Kelurahan Tasikmadu sendiri yang memahami, menginginkan, dan memecahkan permasalahan yang dihadapinya. Posisi peneliti lebih sebagai fasilitator bagi warga Kelurahan Tasikmadu serta memberikan jalan keluar dan merumuskan strategi yang dapat digunakan untuk mencari solusi bagi permasalahan mereka. Namun perumusan jalan keluar dan strategi ini tetap melibatkan para warga dengan harapan setelah pelatihan ini selesai dapat mengetahui tata cara mengurus jenazah yang benar sesuai syariat, meninggalkan tradisi-tradisi yang justru bertentangan dengan tata cara pengurusan yang syar'i.

Penelitian Parsipatory Action Research (PAR) ini bermanfaat untuk memfasilitasi dan memotivasi agar masyarakat khususnya warga mampu:

1. Mengidentifikasi kekuatan dan kelemahan serta problemantikanya dalam hal mengurus jenazah.

2. Menemukenali faktor penyebab minimnya tenaga ahli tata cara pengurusan jenazah dan alternatif solusinya.

3. Menyusun strategi dan metode yang tepat untuk memecahkan permasalahan tentang tata cara pengurusan jenazah.

4. Menyusun rencana aksi berdasarkan prioritas dan keberlanjutan program melalui tahapan-tahapan hingga mencapai target yang diharapkan.

Adapun strategi yang digunakan dalam melakukan action research ini adalah menggunakan metode yang dikemukakan oleh Kurt Lewin dalam Arikunto didasarkan atas konsep pokok bahwa penelitian tindakan yang terdiri empat komponen pokok yang juga menunjukkan langkah, yaitu: a) perencanaan atau planning, b) tindakan atau acting, c) pengamatan atau observing dan d) refleksi atau reflecting. Kemudian model Kurt Lewin ini dikembangkan oleh Kemmis dan Mc Taggart yang menyatukan siklus kedua dan ketiga yaitu tindakan acting dan observing menjadi reflecting, sebagaimana gambar berikut:

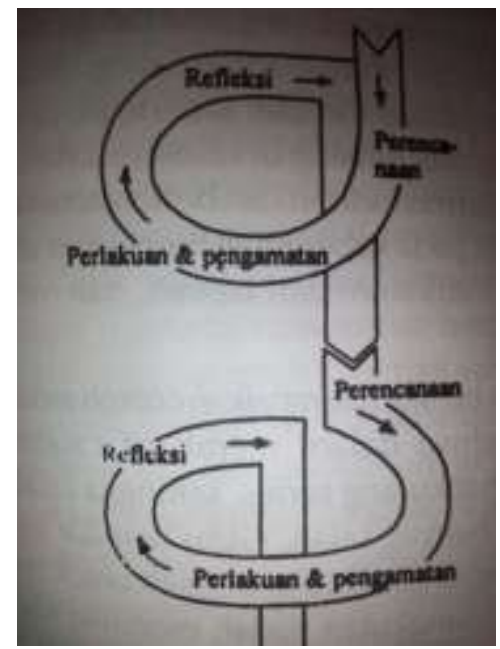

Gambar 1. Alur PAR 
penelitian ini, yaitu:

Dari gambaran proses penelitian action research ini ada empat tahapan dalam melakukan

1. Perencanaan(plan). Perencanaan ini dilakukan setelah memperhatikan kondisi riil di masyarakat dengan menganalisis problemantika minimnya tenaga ahli tata cara pengurusan jenazah dan menganalisis kekuatan, kelemahan, peluang dan ancaman yang mungkin terjadi. Hal ini dilakukan dengan melibatkan warga Tasikmadu kecamatan Lowokwaru Kota Malang. Perencanaan ini meliputi strategi dan metode dalam memecahkan problemantika tentang tata cara mengurus jenazah yang benar sesuai syariat, meninggalkan tradisi-tradisi yang justru bertentangan dengan tata cara pengurusan yang syar'i.

2. Tindakan(action). Setelah proses perencanaan dilakukan, Warga Kelurahan Tasikmadu Kecamatan Lowokwaru Kota Malang mengimplementasikan rencana yang telah dibuat tersebut dengan dibantu dan difasilitatori oleh peneliti.

3. Pengamatan(Observe).Pengamatan dilakukan untuk memperhatikan dan menganalisis keberhasilan, kelemahan, dan kekurangan strategi dan metode yang digunakan dalam menyelesaikan problemantika yang terjadi di masyarakat.

4. Refleksi (Reflect). Usaha-usaha yang telah dilakukan dalam memecahkan kondisi warga di tengah masyarakat tersebut direfleksikan dan dievaluasi, baik kekurangan, kelemahan dan keberhasilan strategi. Refleksi dan evaluasi ini berujung pada perencanaan (plan)seperti pada poin pertama untuk menuntaskan problem yang dihadapi para warga, baik yang belum tuntas pada tahap pertama atau untuk memecahkan problemantika yang baru, sehingga tercapai kondisi dampingan yang diharapkan.

5. Media atau alat praga yang dibutuhkan adalah : semua alat kebutuhan merawat jenazah, meliputi

a. Boneka :sebagai ganti dari manusia/jenazah

b. Peralatan mandi: sabun, sampo,

c. Kain kafan: diajarkan bagaimana cara memotong kain kafan, dipotong sesuai ukuran jenazah, dipotong esuai yang dibutuhkan untuk membungkus jenazah.

d. Perlengkapan: minyakwangi, kapur barus, kayu garu

e. Kain panjang (Jarit) :sebagai alat untuk menutupi mayat sebelum dan sesudah dimandikan.

f. Tikar: digunakan untuk membungkus bagian luar jenazah.

\section{HASIL DAN PEMBAHASAN}

Pengabdian pelatihan jenazah ini melibatkan perempuan, terutama kaum ibu beserta modin perempuan yang bertujuan untuk memberikan pengetahuan dan pemahaman bahwa mengurus jenazah bukanlah tugas seorang modin semata, akan tetapi menjadi tugas bersama.

\subsection{Tahapan Penelitian}

Pelatihan pengurusan jenazah ini dilakukan sesuai dengan tahapan penelitian Partisipatory Action

Research (PAR), yaitu sebagaimana berikut:

3.1.1 Analisis Kebutuhan

Sebelum dilaksanakan kegiatan pelatihan ini, peneliti melakukan analisis kebutuhan kepada pihak kelurahan Tasikmadu dengan melakukan wawancara kepada Bapak Kepala Desa untuk melihat keterkaitan program agar dapat bersinergi dengan masyarakat Tasikmadu, khususnya dalam hal perawatan jenazah bagi kaum perempuan. Dari hasil analisis kebutuhan didapatkan data bahwa yang pernah mendapatkan pelatihan merawat jenazah hanya kaum Bapak saja, sehingga agar sumber daya manusia terutama kaum perempuan berdaya, maka perlu dilakukan pelatihan ini. Apalagi dari hasil pengamatan peneliti, ada banyak tradisi praktik merawat jenazah yang kurang sesuai dengan syariat, sehingga perlu diluruskan.

Sehingga kegiatan pelatihan mengurus dan merawat jenazah ini diperlukan karena bertujuan untuk mengetahui sekaligus mempraktekkan tatacara mengurus jenazah yang benar sesuai syariat serta meninggalkan tradisi-tradisi yang justru bertentangan dengan tata cara pengurusab yang syar'I. Selanjutnya diharapkan peserta nanti mampu mengurus jenazah yang ada di lingkungannya dengan menggunakan tata cara yang dipelajari.

\subsubsection{Koordinasi}

Setelah melakukan analisis kebutuhan, peneliti melakukan koordinasi kepada pihak kelurahan dalam hal ini pelatihan akan melibatkan unsur masyarakat yang didominasi oleh para kaum perempuan yang terdiri dari ibu rumah tangga yang merupakan perwakilan dari tiap-tiap RT, yaitu dari RT 01 diwakili oleh ibu Yuli, RT 02 diwakili oleh ibu Nurdiana, RT 03 diwakili oleh ibu Sulis, RT 04 diwakili 
oleh ibu Rahmawati, RT 05 diwakili oleh ibu Laila Badriyah, dan RT 06 diwakili oleh ibu Rumiyati, sedang dari pihak kelurahan dihadiri oleh ibu Guni. Dalam koordinasi ini dibahas tentang waktu pelaksanaan acara, media yang harus dipersiapkan, unsur masyarakat yang akan hadir dan jumlah peserta.

\subsubsection{Kegiatan Inti}

Pada hari yang telah ditentukan, yaitu tanggal 22-23 Agustus 2019 pada pukul 13.00-15.00 di Aula Kelurahan Tasikmadu dilaksanakan kegiatan Pelatihan mengurus dan merawat jenazah yang dihadiri oleh 40 peserta yang terdiri dari perwakilan tiap RT ditambah bapak dan ibu modin.

Sesuai dengan tahapan penelitian PAR, maka dilakukan tahapan sebagai berikut: Siklus pertama: pada siklus ini peserta pelatihan diberikan materi-materi seputar 1. pahala bagi orang yang merawat jenazah, mulai memandikan, mengkafani, mensalati dan menguburkan; 2. apa yang harus dilakukan pada orang yang sedang sakaratul maut; 3. apa yang harus dilakukan pada orang yang baru saja meninggal; 4. bagaimana cara memandikan jenazah.

Perubahan yang muncul dari peserta pelatihan adalah: Terbangunnya pemahaman konstruktif tentang pahala bagi orang yang merawat jenazah, hal-hal yang harus dilakukan pada orang yang meninggal sekaligus tata cara mengurus jenazah sesuai syariat. Materi-materi tersebut disampaikan secara jelas disertai tanya jawab, juga menanyakan kondisi riil di lapangan seperti apa. Hal ini dilakukan agar peserta semakin paham dan mampu membedakan mana cara yang salah dan menjadi tradisi turunan di masyarakat padahal itu adalah salah, dan mana yang mana benar yang sesuai syariat dan itu harus dipertahankan, mana pula yang harus disempurnakan agar bisa merawat jenazah dengan sebaik-baiknya.

Setiap teori yang disampaikan disertai dengan praktek langsung oleh para peserta, bagaimana sikap dan apa yang harus dilakukan saat ada orang yang tengah sakaratul maut, saat ada orang yang baru meninggal, juga diajarkan bagaimana cara memotong kain kafan dan menuyusunnya. Dalam hal iniTiap-tiap kelompok dituntut untuk bisa.

Siklus kedua: Pada siklus ini para peserta pelatihan pengurusan jenazah mendemostrasikan (melakukan praktikum) materi-materi yang telah diberikan secara langsung melalui media boneka. Para peserta pelatihan pengurusan jenazah ini memulai praktikum dari tahapan-tahapan bagaimana memngurus jenazah dari awal meninggal hingga mempersiapkan proses memandikan, mengkafani, mensalati dan menguburkannya. Dalam hal ini, peserta yang berjumlah 40 orang dibagi menjadi 5 kelompok, dan masing-masing berkumpul untukmendemostrasikan keterampilan mengurus jenazah dengan dipandu oleh peneliti sebagai fasilitator.

Perubahan yang terjadi, peserta langsung mendapatkan pengalaman dalam hal praktikum melalui media boneka, Mereka dapat menerapkan materi yang telah diterima sekaligus melakukan penilaian terhadap kinerja praktikum mereka dengan bantuan fasilitator.

\section{KESIMPULAN}

Penelitian tentang pengurusan jenazah ini mendapatkan respon yang baik dari peserta perempuan dikarenan mereka belum pernah mengikuti pelatihan ini. Berdasarkan hasil di lapangan, terjadi perubahan terhadap siklus pertama dan kedua, terutama saat peserta menggunakan metode dokumentasi.

Penelitian ini juga memberikan peluang untuk dilanjutkan penelitian-penelitian yang lebih berkembang terkait dengan penggunaan metode dan strategi untuk memudahkan pemahaman masyarakat dalam proses pelatihan di bidang keagamaan.

\section{UCAPAN TERIMAKASIH}

Ucapan terima kasih disampaikan kepada LP2M Universitas Islam Negeri Maulana Malik Ibrahim Malang yang telah mendanai kegiatan pengabdian kepada masyarakat, sehingga terlaksana dengan baik. Kepada Kepala desa dan tim kelurahan, masyarakat Tasikmadu ,khususnya para kaum ibu yang tersebar pada RT 1 sanpai RT 5, dan seluruh pihak yang telah membantu jalannya pengabdian ini. Semoga Allah membalas kebaikan semuanya.

\section{DAFTAR PUSTAKA}

Riyadi, Agus, 2013, Upaya Pemberdayaan dan Peningkatan Keterampilan Pemulasaran Jenazah Di Wilayah Kecamatan Mijen Kota Semarang, Jurnal Dimas, Vol. 13 no. 2, pp 201

Noor, Munawar, 2011, Pemberdayaan Masyarakat, Jurnal Ilmiah CIVIS, Vol. I no. 2, pp 87 
Abdullah, Khasan. 2012. Efektifitas Penerapan Metode Demostrasi dalam Mencapai Kemampuan Psikomotorik Siswa pada Mata Pelajaran Fiqh di MA Futuhiyah I Mranggen Demak, Skripsi IAIN Walisongo Semarang

Nurhayati, Eva Syarifah, 2008, Efektivitas Metode Demostrasi Pada Pembelajaran Bidang Studi Fiqih Di MTS Soebono Mantofani Jombang-Ciputat Tangerang, Skripsi Fakultas Ilmu Tarbiyah dan Keguruan UIN Syarif Hidayatullah Jakarta. Fikri, Mumtazul, 2011, Konsep Pendidikan Islam: Pendekatan Metode Pengajaran, Jurnal Ilmiah Islam Futura, Vol. 11 no. 1 , pp 121-122

Arikunto, Suharsimi, 2006, Metode Penelitian, Bandung: Rineka Cipta 